\title{
Chronic Treatment with Novel Brain-Penetrating Selective NOP Receptor Agonist MT-77I6 Reduces Alcohol Drinking and Seeking in the Rat
}

\author{
Roberto Ciccocioppo*,', Serena Stopponi', Daina Economidou', Makoto Kuriyama², Hiroshi Kinoshita ${ }^{2}$, \\ Markus Heilig ${ }^{3}$, Marisa Roberto ${ }^{4}$, Friedbert Weiss ${ }^{5}$ and Koji Teshima ${ }^{2}$ \\ 'Pharmacology Unit, School of Pharmacy, University of Camerino, Camerino, Italy; '2Department II (CNS), Pharmacology Research Laboratories I, \\ Research Division, Mitsubishi Tanabe Pharma Corporation, Yokohama, Japan; ${ }^{3}$ Laboratory of Clinical and Translational Studies, National Institute \\ of Alcohol Abuse and Alcoholism, National Institutes of Health, Bethesda, MD, USA; ${ }^{4}$ Committee on the Neurobiology of Addictive Disorders, \\ The Scripps Research Institute, La Jolla, CA, USA; ${ }^{5}$ Department of Molecular and Cellular Neuroscience, The Scripps Research Institute, La Jolla, \\ CA, USA
}

\begin{abstract}
Since its discovery, the nociceptin/orphanin FQ (N/OFQ)-NOP receptor system has been extensively investigated as a promising target to treat alcoholism. Encouraging results obtained with the endogenous ligand N/OFQ stimulated research towards the development of novel brain-penetrating NOP receptor agonists with a pharmacological and toxicological profile compatible with clinical development. Here we describe the biochemical and alcohol-related behavioral effects of the novel NOP receptor agonist MT-77I6. MT-77I 6 has high affinity for human NOP receptors expressed in HEK293 cells with a Ki value of 0.21 nM. MT-77I 6 concentration-dependently stimulated $\mathrm{GTP}^{35} \mathrm{~S}$ binding with an $\mathrm{EC}_{50}$ value of $0.30 \mathrm{nM}$ and its efficacy was similar to N/OFQ, suggesting that MT77/6 is a full agonist at NOP receptors. In the two bottle choice test MT-77I6 (0,0.3, I, and $3 \mathrm{mg} / \mathrm{kg}$, bid) given orally for 14 days dose-dependently decreased voluntary alcohol intake in Marchigian Sardinian rats. The effect became gradually stronger following repeated administration, and was still significant I week after discontinuation of the drug. Oral naltrexone $(30 \mathrm{mg} / \mathrm{kg}$, bid) for 14 days also reduced ethanol intake; however, the effect decreased over the treatment period and rapidly disappeared when drug treatment was discontinued. MT-77I 6 is also effective for preventing reinstatement caused by both ethanol-associated environmental stimuli and stress. Finally, to investigate the effect of MT-77I 6 on alcohol withdrawal symptoms, Wistar rats were withdrawn from a 7-day alcohol liquid diet. MT-77I 6 significantly attenuated somatic alcohol withdrawal symptoms. Together these findings indicate that MT-77/6 is a promising candidate for alcoholism treatment remaining effective with chronic administration.

Neuropsychopharmacology (20 I4) 39, 260 I-26I0; doi:I0. I038/npp.20 I4.II3; published online 2 July 20I4
\end{abstract}

\section{INTRODUCTION}

Nociceptin/orphanin FQ (N/OFQ) is the endogenous ligand of the NOP receptor, also referred to as the opioid receptorlike 1 receptor (Meunier et al, 1995; Reinscheid et al, 1995). Since its discovery in 1995, the role of N/OFQ in the regulation of reward mechanisms has been extensively investigated in animal models of substance abuse such as conditioned place preference and self-administration. The results of these studies demonstrated that activation of the NOP receptor counteracts the rewarding effects of morphine (Ciccocioppo et al, 2000b; Di Giannuario and Pieretti, 2000; Mogil et al, 1996b; Murphy et al, 1999), cocaine,

\footnotetext{
*Correspondence: Professor R Ciccocioppo, School of Pharmacy, Pharmacology Unit, University of Camerino, Via Madonna delle Carceri, Camerino, 62032, Italy, Tel: +390737 403313, Fax: +390737 403325, E-mail: roberto.ciccocioppo@unicam.it

Received 23 January 2014; revised 31 March 2014; accepted 22 April 2014; accepted article preview online 27 May 2014
}

methamphetamine (Kotlinska et al, 2002; Marquez et al, 2013; Zhao et al, 2003), nicotine (Sakoori and Murphy, 2009), and alcohol (Ciccocioppo et al, 2002a; Ciccocioppo et al, 2004a; Ciccocioppo et al, 2004b; Kuzmin et al, 2007; Martin-Fardon et al, 2000). A link between the NOP system and addiction has been also suggested by association studies in humans in which a single nucleotide polymorphism (SNP rs6010718) in the gene encoding for the NOP receptor has been linked to alcohol abuse (Huang et al, 2008). In another study, two adjacent SNPs on intron 1 of NOP receptor were associated with opioid dependence (Xuei et al, 2008). Moreover, increased vulnerability to alcohol dependence has been recently linked to DNA hypermethylation of the promoter regions of several genes, including the one encoding for the NOP receptor (Zhang et al, 2013).

In animal models of reinstatement, stimulation of NOP receptors by N/OFQ also blocks reinstatement of extinguished ethanol-seeking behavior induced by exposure to ethanol-associated environmental stimuli and footshock 
stress (Ciccocioppo et al, 2002a, 2004a, 2004b; Kuzmin et al, 2007; Martin-Fardon et al, 2000). In relation to this latter effect, the NOP receptor system has been suggested to act as a functional antagonist of the corticotrophin releasing factor (CRF) in extrahypothalamic areas (Ciccocioppo et al, 2004a). These findings are consistent with the high vulnerability to social stress and anxiety observed in knockout mice for the N/OFQ precursor peptide compared with wild type (Koster et al, 1999). Anxiolytic-like properties of N/OFQ were also demonstrated during a stressful and critical phase of substances addiction, the withdrawal period (Aujla et al, 2012; Economidou et al, 2011). For instance, N/OFQ markedly reduced the expression of somatic and emotional withdrawal signs during acute or protracted withdrawal in alcohol-dependent rats (Aujla et al, 2012; Economidou et al, 2011).

These findings obtained with the endogenous ligand N/OFQ stimulated growing interest in the development of novel NOP receptor agonists to be tested in alcoholism. Ro 64-6198 was the first reported nonpeptidic brain-penetrating NOP receptor agonist (Jenck et al, 2000), and has been tested on alcohol-related behaviors. Although Kuzmin et al (2007) reported that Ro 64-6198 reduced alcohol selfadministration in Wistar rats, we found that the compound increased alcohol intake in genetically selected Marchigian Sardinian $(\mathrm{msP})$ alcohol-preferring rats (Economidou et al, 2006). Hence, whereas cumulative evidence obtained with N/OFQ directly delivered into the CNS strongly supports NOP agonism as a promising option for alcohol addiction treatment, data so far obtained following systemic administration of brain-penetrating NOP agonists remain inconclusive.

Here we describe a recently developed molecule, MT7716, with high affinity and selectivity for NOP receptors and that has pharmacological properties compatible with clinical development. Using msP rats MT-7716 was studied on alcohol drinking and on reinstatement to alcohol seeking. Moreover, to increase the translational value of our study we tested the effect of MT-7716 following chronic administration. Finally, we explored the ability of this NOP agonist to attenuate the expression of somatic withdrawal symptoms following chronic alcohol intoxication.

\section{MATERIALS AND METHODS}

\section{Animals}

Alcohol drinking and reinstatement studies were carried out in male genetically selected alcohol-preferring $\mathrm{msP}$ rats. MsP rats were 2-4 months old at the beginning of the experiments, and were single housed on a reverse $12: 12 \mathrm{~h}$ light/dark cycle (lights off at $0930 \mathrm{~h}$ ), at a temperature of 20$22{ }^{\circ} \mathrm{C}$ and a humidity of $45-55 \%$, with free access to tap water and food pellets (4RF18, Mucedola, Settimo Milanese, Italy). For the alcohol withdrawal experiment, male Wistar rats, purchased from Charles River Japan (Yokohama, Japan) were used. Wistar rats were 6-7 weeks old at the beginning of the experiment, and were housed in groups of four per cage on a normal $12: 12 \mathrm{~h}$ light/dark cycle (light on at $0900 \mathrm{~h}$ ), at a temperature of $23^{\circ} \mathrm{C}$ (permissible range: $20-26^{\circ} \mathrm{C}$ ), relative humidity of $55 \%$ (permissible range: $30-70 \%$ ) with free access to water and standard foods pellets (MF, Oriental Yeast, Tokyo, Japan). All the procedures were conducted in adherence with the European Community Council Directive for Care and Use of Laboratory Animals and the National Institutes of Health Guide for the Care and Use of Laboratory Animals, or in accordance with the guidelines for animal experimentation set by the Ethics Committee for Animal Use at Mitsubishi Tanabe Pharma Corporation.

\section{Drugs and Chemicals}

MT-7716,(R)-2-\{3-[1-(acenaphthen-1-yl)piperidin-4-yl]-2oxo-2,3-dihydro- $1 H$-benzimidazol-1-yl $\}-N$-methylacetamide hydrochloride hydrate, Ro 64-6198, J-113397 (non-peptidergic NOP receptor antagonist) and diazepam were synthesized at Mitsubishi Tanabe Pharma Corporation. N/OFQ, naltrexone hydrochloride, acamprosate calcium, and yohimbine hydrochloride were purchased from Alexis Biochemicals, TOCRIS Bioscience, Toronto Research Chemicals, and Sigma-Aldrich, respectively. $\left[{ }^{3} \mathrm{H}\right]$ nociceptin and $\left[{ }^{3} \mathrm{H}\right]$ DAMGO were purchased from GE Healthcare and PerkinElmer, respectively. For in vitro receptor binding assays, all test drugs were dissolved in dimethyl sulfoxide and diluted with incubation buffer to the appropriate concentrations. For all in vivo experiments, MT-7716 and naltrexone were dissolved in distilled water; diazepam was suspended in $0.5 \%$ carboxymethylcellulose sodium solution and administered orally. Yohimbine was dissolved in saline and injected intraperitoneally (ip).

\section{Biochemical Assays}

In vitro receptor binding, GTP $\gamma^{35} \mathrm{~S}$ binding and enzyme inhibition assays were performed to characterize the biochemical profile of MT-7716. NOP and $\mu$-opioid receptor binding assays were conducted in-house (Mitsubishi Tanabe Pharma Corporation); the other assays were performed by contract at MDS Pharma Services (present name: Eurofins Panlabs Taiwan). For NOP receptor assays, membrane protein prepared from a stable recombinant cell line expressing human NOP receptor was purchased from ParkinElmer and incubated for $60 \mathrm{~min}$ at $25^{\circ} \mathrm{C}$ with $\left[{ }^{3} \mathrm{H}\right] \mathrm{N} / \mathrm{OFQ}$ (final concentration: $0.1 \mathrm{nM}$ ) in incubation buffer containing $50 \mathrm{mM}$ HEPES, $1.1 \mathrm{mM}$ EDTA, $10 \mathrm{mM} \mathrm{MgCl}_{2}, 0.1 \%$ BSA, and $0.1 \%$ protease inhibitor cocktail (Sigma-Aldrich) $(\mathrm{pH}$ 7.4). The reaction was terminated by filtration through Whatman GF/B filters and rinsing three times with $3 \mathrm{ml}$ of ice-cold washing buffer containing $50 \mathrm{mM}$ HEPES, $1.1 \mathrm{mM}$ EDTA, and $10 \mathrm{mM} \mathrm{MgCl} 2$ (pH 7.4). Nonspecific binding was determined in the presence of J-113397 $(200 \mu \mathrm{M})$. For $\mu$-opioid receptor assay, membrane protein prepared from stable recombinant cell lines expressing human $\mu$-opioid receptor were purchased from ParkinElmer, and incubated for $60 \mathrm{~min}$ at $25^{\circ} \mathrm{C}$ with $\left[{ }^{3} \mathrm{H}\right]$ DAMGO (final concentration: $0.5 \mathrm{nM}$ ) in incubation buffer containing $50 \mathrm{mM}$ Tris- $\mathrm{HCl}$ buffer, $5 \mathrm{mM} \mathrm{MgCl}_{2}, 0.1 \% \mathrm{BSA}$, and $0.1 \%$ protease inhibitor cocktail ( $\mathrm{pH}$ 7.4). The reaction was terminated by filtration through Whatman GF/B filters and rinsing three times with $3 \mathrm{ml}$ of ice-cold $50 \mathrm{mM}$ Tris- $\mathrm{HCl}$ buffer ( $\mathrm{pH}$ 7.4). Nonspecific binding was determined in the presence of naltrexone $(200 \mu \mathrm{M})$. $\mathrm{Ki}$ and $\mathrm{EC}_{50}$ values were expressed by 
geometric mean $(95 \%$ confidence intervals) of three independent assays.

\section{Two Bottle Choice Test Cages}

Home cages ( $30 \mathrm{~cm}$ long $\times 30 \mathrm{~cm}$ wide $\times 30 \mathrm{~cm}$ high) equipped with two burettes (volume: $100 \mathrm{ml}$ ) with metallic drinking spouts and food containers were used to measure ethanol, water, and food consumption.

\section{Self-Administration Chambers}

Standard operant chambers (Med Associate) located in sound-attenuating, ventilated environmental cubicles were used. Each chamber was equipped with a drinking reservoir (volume capacity: $0.30 \mathrm{ml}$ ) positioned $4 \mathrm{~cm}$ above the grid floor in the center of the front panel of the chamber, and two retractable levers, one was the ethanol-paired active lever and the other was the inactive control lever, located $3 \mathrm{~cm}$ to the right and to the left of the drinking reservoir. Fluid delivery, count of the number of lever presses, and presentation of visual stimuli (illumination of a house light), were controlled by an IBM compatible computer.

\section{Effect on Ethanol Drinking in msP Rats}

Rats were maintained in a vivarium room on a reverse $12: 12 \mathrm{~h}$ light/dark cycle (lights off at $0930 \mathrm{~h}$ ). At the age of 3 months, msP rats $(n=48)$ were selected for their preference for $10 \%$ ethanol solution $(\mathrm{v} / \mathrm{v})$, by offering them free choice between water and $10 \%$ ethanol $24 \mathrm{~h}$ a day. After 15 days of choice-drinking, 45 rats were selected for high ethanol preference and were used in the experiments. To test the effect of chronic MT-7716 administration on ethanol drinking, msP rats were given vehicle for 3 days to familiarize them with the oral administration procedure. Animals then were divided into five groups ( $n=9$ /group) with similar baseline ethanol consumption, water consumption, and body weight. MT-7716 and naltrexone hydrochloride were administered orally twice a day (first administration at $0830 \mathrm{~h}$, second administration at $1630 \mathrm{~h}$ ). Ethanol, water, and food intake were monitored $24 \mathrm{~h}$ /day from the first administration throughout the entire treatment period. At the end of the treatment, ingestive behaviors were monitored for additional 14 days.

\section{Effect on Cue-Induced Reinstatement to Ethanol Seeking in msP Rats}

Conditioning phase. Animals were trained to discriminate between $10 \%$ alcohol and water as previously described (Cannella et al, 2009). The purpose was to train rats to discriminate the availability of alcohol (reward) vs water (non-reward). Briefly, conditioning sessions consisted of 20 randomly distributed 30 -min daily sessions ( 10 for alcohol and 10 for water), during which discriminative stimuli (SD) predictive of alcohol $v s$ water availability were presented. The SD for alcohol consisted of the odor of an orange extract $(S+)$, whereas water availability was signaled by an anise extract $(S-)$. The olfactory stimuli were produced by depositing five to six drops of the respective extract into the bedding of the operant chamber immediately before extension of the levers and session initiation, and remained present throughout the 30 -min sessions. In addition, each lever press resulting in delivery of alcohol was paired with illumination of the chamber's house light for $5 \mathrm{~s}$, while lever presses resulting in water delivery were followed by a 5-s white noise. Concurrently with the presentation of these stimuli, a 5-s time-out (TO) period was in effect, during which responses were recorded, but not reinforced by alcohol or water.

Extinction phase. After completion of the conditioning phase, rats were subjected to 30 -min extinction sessions for 13 consecutive days. Extinction sessions began by extension of the levers without presentation of the olfactory discriminative stimuli. Responses at the previously active lever activated the syringe pump but did not result in the delivery of either alcohol or water or the presentation of the response-contingent cues (house light or white noise). This phase was introduced to eliminate the capacity of the selfadministration chamber to non-specifically motivate the animal's behavior but leaving unaltered the ability of the cues to predict alcohol availability. During extinction day 5,6 , and $7,1 \mathrm{~h}$ before each session, animals were orally given $1 \mathrm{ml}$ of distilled water to familiarize them with the administration procedure. On extinction day 8, rats were divided into three groups with similar baseline levels of responses. The first group $(n=8)$ was treated with drug vehicle, whereas the second group $(n=8)$ and the third group $(n=9)$ received MT-7716 at doses of 0.3 and $1.0 \mathrm{mg} / \mathrm{kg}$, respectively. MT-7716 was administered twice a day for 6 consecutive days, $1 \mathrm{~h}$ before the self-administration session and $8 \mathrm{~h}$ later.

Reinstatement phase. After completion of the discrimination and extinction phases, animals were tested for the ability of MT-7716 to prevent the reinstatement of alcoholseeking behavior elicited by cues predictive of alcohol availability. Animals were tested under the $S+$ condition on day 1 and the $S-$ condition on day 2. During the reinstatement tests alcohol and water were not available. Responding at the inactive lever was recorded to monitor possible nonspecific behavioral effects.

\section{Effect on Yohimbine-Induced Reinstatement to Ethanol Seeking in msP Rats}

Training phase. At the age between 2 and 3 months, msP rats $(n=48)$ were trained to self-administer ethanol solution in 30-min daily sessions under an FR1 schedule of reinforcement, in which each response at the ethanol-paired active lever resulted in delivery of $0.1 \mathrm{ml}$ of fluid, while responses at the inactive lever resulted in no fluid delivery. Each ethanol delivery was associated with $5 \mathrm{~s}$ TO signaled by illumination of the house light. Alcohol self-administration training was continued until stable baselines of responding were established. Water and food were freely available in the home cages during the entire experimental period.

Extinction phase. After the last ethanol self-administration session, animals were subjected to 30 -min extinction sessions for 15 consecutive days. The procedure for 
extinction sessions was the same as for ethanol selfadministration sessions, except that ethanol solution was no longer available. Animals were pre-treated with vehicle for 3 days before the initial administration of MT-7716 to familiarize them with the oral administration procedure. Rats then were divided into four groups ( $n=12$ /group) with similar number of lever presses and body weights over the last 3 days of the training phase. MT-7716 $(0.3,1$, and $3 \mathrm{mg} / \mathrm{kg}$ ) was administered twice a day, $1 \mathrm{~h}$ before and $8 \mathrm{~h}$ after the operant sessions during the last 7 days of extinction phase and $1 \mathrm{~h}$ before the reinstatement test.

Yohimbine-induced reinstatement. msP rats are highly sensitive to stress, which can cause freezing in these animals (Hansson et al, 2006). Hence, to attenuate the expression of this competing behavior, the day before the reinstatement test all $\mathrm{msP}$ rats received an ip injection of yohimbine $(2.0 \mathrm{mg} / \mathrm{kg})$ to pre-expose them to the stress-like effect of this $\alpha 2$ antagonist. The following day, during the reinstatement test, yohimbine $(2.0 \mathrm{mg} / \mathrm{kg})$ was given $30 \mathrm{~min}$ before the sessions and the effect of MT7716 was evaluated.

\section{Effect on Ethanol Withdrawal Symptoms in Wistar Rats}

As $\mathrm{msP}$ rats have a relatively low sensitivity to the intoxicating effects of alcohol here, to facilitate the analysis of MT-7716 effects on alcohol withdrawal, male Wistar rats $(N=80)$ were used. After acclimation, rats were given control liquid diet (Dyets, USA) for 2 days. Next, all rats were provided with an ethanol liquid diet (Dyets, USA) containing $6.7 \%(\mathrm{v} / \mathrm{v})$ ethanol for 7 days. The body weight of the animals was recorded every day, and daily diet intake was measured and expressed as grams per four rats. Rats were given access to the liquid diet as the only source of calories throughout the experiment. After receiving ethanol liquid diet for 7 days, all rats were withdrawn from ethanol by substituting control liquid diet for the ethanol liquid diet. At 2, 3, 4, 5, 6, 7, 8, and $9 \mathrm{~h}$ after ethanol withdrawal, all rats were rated for symptoms of withdrawal according to the method of Macey et al (1996). Four symptoms were scored: ventromedial limb retraction (measured by grasping the rat by scruff of the neck and checking for retraction of the hind limbs towards the body), vocalization (measured by the intensity and frequency), tail rigidity (characterized by the presence of a rigid, awkwardly bent tail), and tail tremor (measured by the duration and frequency). Rats were scored for symptoms of withdrawal according to the following rating scale $(0=$ not present; $1=$ moderate; $2=$ severe). Rats with a total score of 1 and below at $4 \mathrm{~h}$ after ethanol withdrawal were excluded from the experiment. Ethanol-treated rats were divided into four groups and test compounds or vehicle were orally administered $5 \mathrm{~h}$ after ethanol withdrawal. The effects of drug treatment were evaluated at $1,2,3$, and $4 \mathrm{~h}$ after administration $(6,7,8$, and $9 \mathrm{~h}$ after ethanol withdrawal). Rating of withdrawal symptoms was done by an observer blind to treatment conditions.

\section{Statistical Analysis}

Two bottle choice test. All data are expressed as the mean \pm SEM. The analyses were performed for treatment
(Day 1-14) and post treatment (Day 15-28) period separately. Data were analyzed by mixed-factorial analysis of variance (ANOVA), with treatment as the betweensubjects factor (treatment) and time (days) as the withinsubjects factor. Following confirmation of a significant main effects for 'treatment' or a significant 'treatment $x$ time' interaction, post-hoc comparisons were performed by Dunnett's multiple comparison test (MT-7716 vs vehicle) or unpaired Student's $t$-test (Naltrexone $v s$ vehicle). A $p<0.05$ value was set to indicate statistical significant difference.

Reinstatement test. The effects of MT-7716 on cue- and yohimbine-induced reinstatement were analyzed by oneway ANOVA with treatment as between subjects factor. Post-hoc analyses were conducted by Dunnett's multiple comparison test. Differences between responses during the extinction and reinstatement sessions were analyzed in the vehicle-treated group by one-way within-subjects ANOVA, followed by paired Student's $t$-test. To control for nonspecific effects, the same statistical approach was used to evaluate inactive lever presses. The number of lever presses is represented as mean \pm SEM.

A $p<0.05$ value was set to indicate statistical significant difference.

Withdrawal symptoms experiment. The sum (area under curve) of the individual symptom or total score $6,7,8$, and $9 \mathrm{~h}$ after ethanol withdrawal was analyzed by Dunnett's multiple comparison test and, when a significant difference was observed, the comparison with the vehicle group at each time point was done by Steel's test. The primary endpoint of ethanol withdrawal was used as the total score representing the sum of the individual scores assessed for the four symptoms. A $p<0.05$ value was set to indicate statistical significant difference.

\section{RESULTS}

\section{Biochemical Profile of MT-7716}

MT-7716 showed high affinity for human NOP receptors expressed in HEK293 cells with a Ki value of $0.21(0.13-$ $0.35) \mathrm{nM}$, and moderate affinity for human $\mu$-opioid receptors expressed in $\mathrm{CHO}$ cells with a $\mathrm{Ki}$ value of 35 (11-120) nM (Table 1). The affinity of MT-7716 for the NOP receptor was almost equal to that of the endogenous agonist $\mathrm{N} / \mathrm{OFQ}$, and higher than that of another nonpeptidic NOP receptor agonist, Ro 64-6198, and a nonpeptidic antagonist, J-113397. Naltrexone and acamprosate did not show affinity for the NOP receptors (Table 2). MT-7716 has 170-fold selectivity for the NOP receptor over the $\mu$-opioid receptor. Although MT-7716 showed low affinities for human serotonin transporters and rat peripheral benzodiazepine receptors with Ki values of 147 (115-188) and 207 (108396) nmol respectively, it had no significant affinity for 110 other receptors or channel-binding sites (see Supplementary Appendix A, Supplementary Material). MT-7716 also did not inhibit 38 major enzyme activities (see Supplementary Appendix B, Supplementary Material).

NOP receptor agonistic activity of MT-7716 was evaluated by $\mathrm{GTP} \gamma^{35} \mathrm{~S}$ binding to human NOP receptor expressed 
Table I Binding Affinity of MT-77I6 for NOP, MOP, DOP, KOP Receptors, Serotonin Transporter and Peripheral Benzodiazepine Receptor

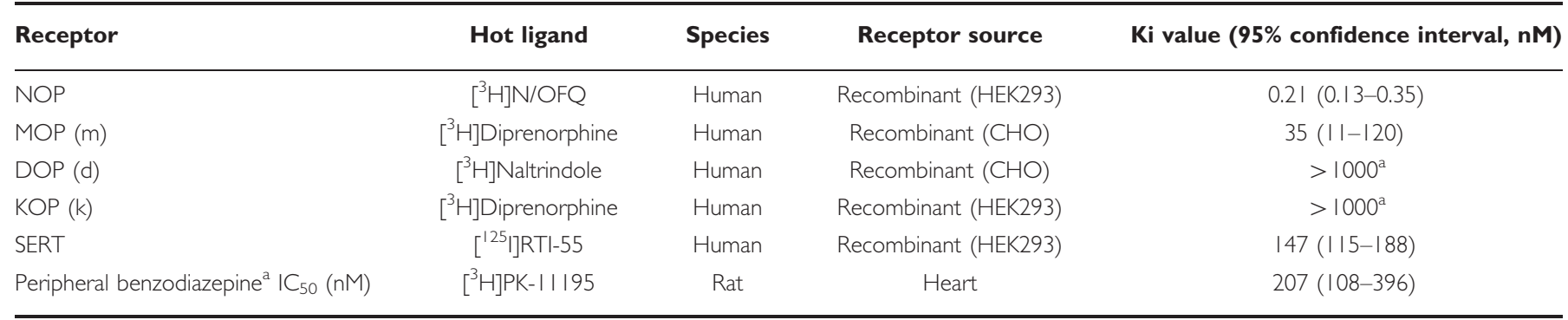

${ }^{\mathrm{a} A f f i n i t y .}$

Table 2 Binding Affinity of MT-77I6 and Reference Compounds for NOP and $\mu$-Opioid Receptors

\begin{tabular}{lcc}
\hline Compound & NOP receptor & $\boldsymbol{\mu}$-Opioid receptor \\
\hline N/OFQ & $0.26(0.082-0.85)$ & $430(260-730)$ \\
MT-77I6 & $0.21(0.13-0.35)$ & $35(11-120)$ \\
Ro 64-6198 & $0.62(0.37-1.0)$ & $19(8.0-45)$ \\
J-II3397 & $4.0(2.5-6.3)$ & $82(42-160)$ \\
Naltrexone & $>1000 *$ & $0.29(0.14-0.60)$ \\
Acamprosate & $>1000 *$ & $>1000 *$
\end{tabular}

Ki values ( $\mathrm{nM}$ ) were expressed by geometric mean ( $95 \%$ confidence intervals) of 3 independent assays. *: $I_{50}$.

in HEK293 cells. MT-7716 concentration-dependently stimulated $\mathrm{GTP} \gamma^{35} \mathrm{~S}$ binding with an $\mathrm{EC}_{50}$ value of 0.30 $(0.18-0.48) \mathrm{nM}$. Its potency was slightly higher than that of N/OFQ (EC 50 value: $1.13(0.70-1.83) \mathrm{nM})$. The maximum effect was almost equal to that of N/OFQ, suggesting that MT-7716 is a full agonist for NOP receptors. The $\mu$-opioid receptor agonist activity of MT-7716 was estimated by GTP ${ }^{35}$ S binding using human $\mu$-opioid receptor expressing CHO cells. MT-7716 concentration-dependently stimulated GTP $\gamma^{35}$ S binding with a $\mathrm{EC}_{50}$ value of $158(96.9-258) \mathrm{nM}$. Its maximum effect was similar to the widely used $\mu$-opioid receptor full agonist DAMGO, suggesting MT-7716 is a full agonist for $\mu$-opioid receptors, but its potency was largely weaker than that of DAMGO ( $\mathrm{EC}_{50}$ value: 6.54 (5.697.51) nmol).

\section{MT-7716 Suppresses Ethanol Drinking in msP Rats}

ANOVA revealed a significant dose-dependent reduction of ethanol intake during the treatment period with MT-7716 (treatment: $\mathrm{F}(3,32)=15.24, \quad p<0.01$; treatment $\times$ time: $\mathrm{F}(39,416)=5.39, p<0.01) \quad$ (Figure 1a). Interestingly, the effect was persistent also during the posttreatment period (treatment: $F(3,32)=17,45, p<0.01$; treatment $\times$ time: $F(39,415)=8.50, p<0.01)$. For naltrexone, ANOVA revealed a significant reduction of ethanol intake during the treatment period (treatment: $\mathrm{F}(1,16)=21.79$; treatment $\times$ time: $\quad p<0.01, \quad \mathrm{~F}(13,208)=2.99, \quad p<0.01)$ (Supplementary Figure 1A), but no effect was observed during the posttreatment period (treatment: $\mathrm{F}(1,16)=0.15$, $p=0.71$; treatment $\times$ time: $\mathrm{F}(13,208)=1.73, p=0.06)$.
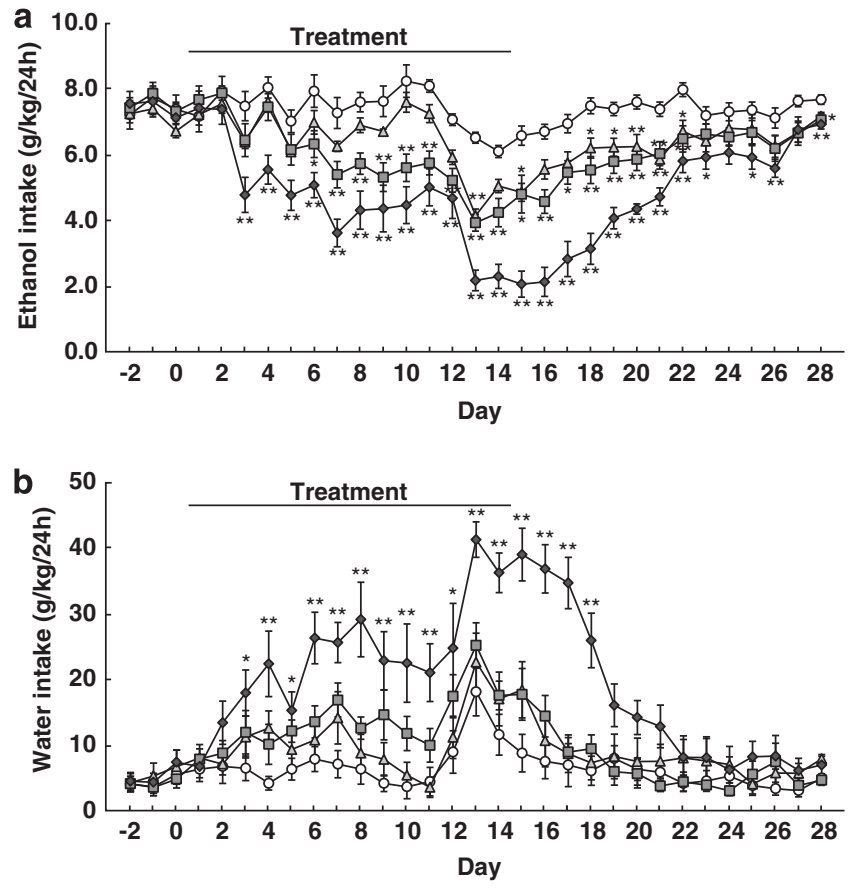

Figure I Effect of MT-77/6 on daily ethanol intake (a) and water intake (b) in a two-bottle free choice paradigm in Marchigian Sardinian (msP) rats. During the treatment period, animals were given MT-77I 6 twice a day for 14 consecutive days, I $\mathrm{h}$ before and $8 \mathrm{~h}$ after the initiation of the dark phase of the light/dark cycle. Ethanol intake and water intake were measured after $24 \mathrm{~h}$ from the initiation of the dark cycle. Repeated measures analysis of variance (ANOVA) followed by Dunnett's multiple comparison test was performed for treatment (Day I-14) and withdrawal (Day 15-28) periods separately. Each data point represents a mean \pm SEM of 8 or 9 rats. Vehicle (○), MT-77I6 $0.3 \mathrm{mg} / \mathrm{kg}(\triangle), I \mathrm{mg} / \mathrm{kg}(\square, 3 \mathrm{mg} / \mathrm{kg}(\diamond), \quad * p<0.05$, *** $<$ <0.0I.

ANOVA revealed that MT-7716 also increased water intake during the treatment period (treatment: $\mathrm{F}(3,32)=$ 9.44, $p<0.01$; treatment $\times$ time: $\mathrm{F}(39,416)=2.16, p<0.01)$, as well as the posttreatment period (treatment; $\mathrm{F}(3,32)=$ $17.45, p<0.01$; treatment $\times$ time: $\mathrm{F}(39,415)=8.50, p<0.01)$ (Figure 1b). Conversely, naltrexone reduced water intake during the treatment period (treatment: $\mathrm{F}(1,16)=0.54$, $p=0.47$; treatment $\times$ time: $\mathrm{F}(13,208)=4.34, p<0.01)$, but not the posttreatment period (Supplementary Figure 1B).

With regard to food intake, ANOVA revealed an inhibitory effect on feeding for both MT-7716 (treatment: $\mathrm{F}(3,32)=1.07, p=0.37$; treatment $\times$ time: $\mathrm{F}(39,416)=2.26$, 


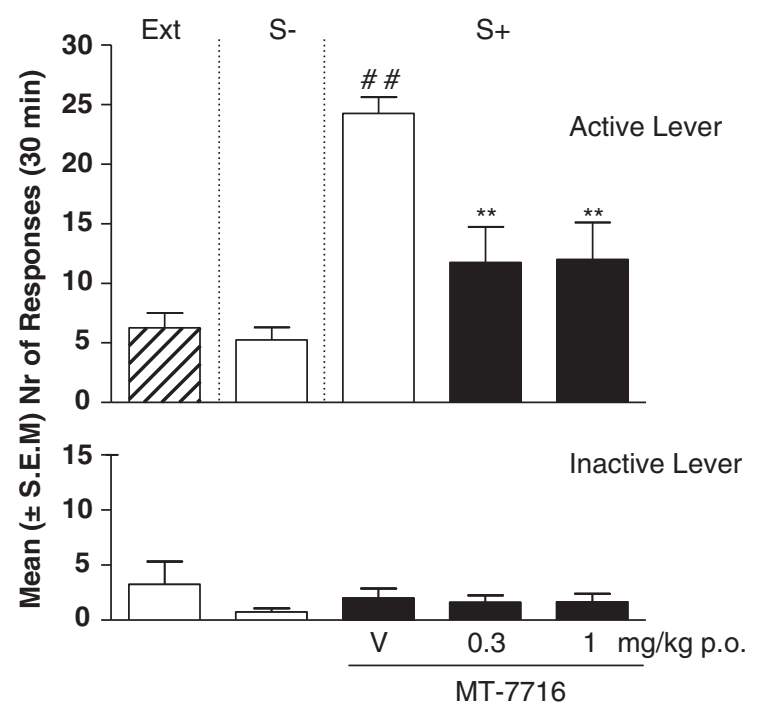

Figure 2 Effect of subchronic treatment with MT-77I6 on cue-induced reinstatement of alcohol-seeking behavior in Marchigian Sardinian (msP) rats. Animals were orally administered MT-77/6 at doses of 0.3 and $1.0 \mathrm{mg} / \mathrm{kg}$ twice a day for 6 consecutive days, I h before and $8 \mathrm{~h}$ after each session during the last 6 days in extinction phase and I h before the reinstatement test. Each bar represents the mean \pm SEM of 8 to 9 rats. $* *$ $p<0.0$ I denotes differences from vehicle treated group (Dunnett's multiple comparison test). ${ }^{\#} p<0.05,{ }^{\#} p<0.01$ denote differences from extinction performance within each respective group (paired Student's t-test).

$p<0.01$ ) and naltrexone (treatment: $\mathrm{F}(1,16)=9.14, p<0.01$; treatment $\times$ time: $F(13,208)=1.56, p=0.10)$ during the treatment period (data not shown).

\section{MT-7716 Suppresses Cue-Induced Reinstatement to Ethanol Seeking in msP Rats}

Results showed that throughout the conditioning phase in which animals discriminated between alcohol or water availability, rats responded at higher levels for alcohol. On the last day of the discrimination period, animals reached a leverpressing response of $74.5 \pm 5.4$ for alcohol, while the responses for water was $29.1 \pm 1.9$. Lever pressing progressively decreased throughout the 13-day extinction phase. ANOVA revealed a non-significant effect of MT-7716 on active lever responses during the last 6 days of extinction phase. Paired Student's $t$-test revealed that the number of active lever responses was increased by cues predictive of alcohol availability $(\mathrm{S}+)$ compared with the last extinction session (Figure 2). Dunnett's multiple comparison test revealed that MT-7716 significantly suppressed the $S+$ stimulus-induced increase of active lever responses at doses of $0.3 \mathrm{mg} / \mathrm{kg}$ $(p<0.01)$ and $1.0 \mathrm{mg} / \mathrm{kg}(p<0.01)$, whereas the number of active lever responses under the $S-$ stimulus condition remained at extinction levels (Figure 2). Responses on the inactive lever were almost absent throughout all experimental phases and were not modified by MT-7716 treatment.

\section{MT-7716 Suppresses Yohimbine-Induced Reinstatement to Ethanol Seeking in msP Rats}

During the self-administration training period, rats rapidly acquired a stable baseline of responding (final self-administration day: $51.6 \pm 2.6$ ). During extinction, responses at

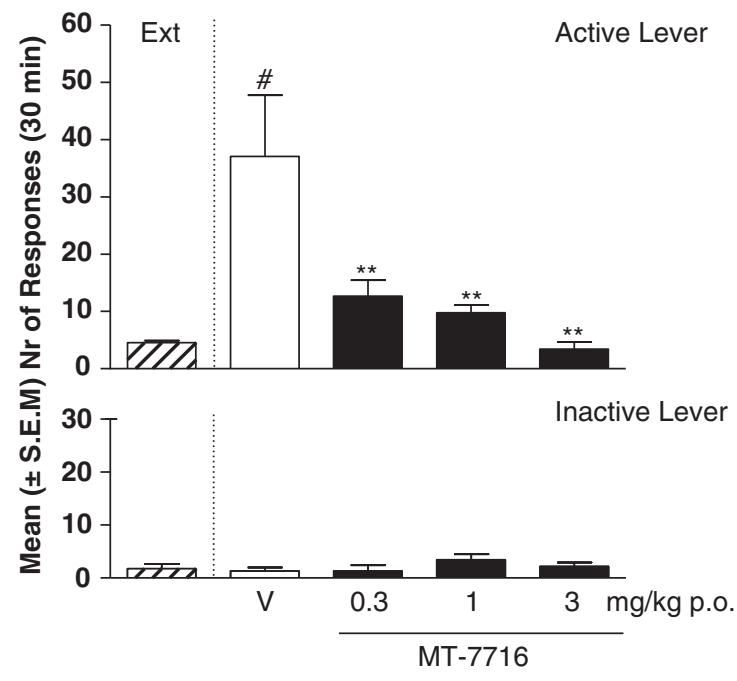

Figure 3 Effect of subchronic treatment with MT-77I6 on yohimbineinduced reinstatement of alcohol seeking in Marchigian Sardinian (msP) rats. Animals were orally administered MT-7716 at doses of $0.3,1$, and $3 \mathrm{mg} / \mathrm{kg}$ twice a day for consecutive 7 days, I h before and $8 \mathrm{~h}$ after the operant sessions and I h before the reinstatement test. Yohimbine at $2 \mathrm{mg} / \mathrm{kg}$ was intraperitoneally injected to rats $30 \mathrm{~min}$ before the beginning of the reinstatement tests. Each bar represents mean \pm SEM of 12 rats. $* p<0.05$, *** $p<0.01$ denote difference from vehicle treated group (Dunnett's multiple comparison test). ${ }^{\#} p<0.05$ denotes difference from extinction performance within vehicle $(\mathrm{V})$ treated group (paired Student's $t$-test).

the active lever progressively decreased. Inactive lever responses remained very low throughout the 15-day extinction phase. ANOVA revealed a nonsignificant effect of MT-7716 on both active and inactive lever responses during the last 6 days of extinction phase. The reinstatement test was repeated on a second consecutive day, because the first injection of yohimbine caused substantial freezing in $\mathrm{msP}$ rats due to their high susceptibility to stress. In the second reinstatement test, paired Student's $t$-test revealed that the number of active lever responses was significantly increased by yohimbine compared with that in the last extinction session: $36.9 \pm 10.7$ vs $4.6 \pm 0.4 \quad(p<0.05)$ in vehicle-treated controls. Dunnett's multiple comparison test revealed that MT-7716 significantly suppressed the yohimbine-induced increase of active responses at doses of $0.3 \mathrm{mg} / \mathrm{kg} \quad(p<0.05), \quad 1 \mathrm{mg} / \mathrm{kg} \quad(p<0.01), \quad$ and $3 \mathrm{mg} / \mathrm{kg}$ $(p<0.01)$. Responses at the inactive lever were almost absent throughout all experimental phases and not affected by MT-7716 treatment (Figure 3).

\section{MT-7716 Attenuates the Expression of Somatic Withdrawal Signs in Wistar Rats}

The effects of MT-7716 and diazepam on ethanol withdrawal symptoms are shown in Figure 4a and b, respectively. Total score (vocalization, ventromedial limb retraction, tail rigidity, and tail tremor) increased over withdrawal time and reached a plateau between 4 and $5 \mathrm{~h}$ into withdrawal. No statistically significant differences between the four groups of rats were observed before drug treatments. Following MT-7716 administration, a significant decrease in the total withdrawal score was observed at $3 \mathrm{mg} / \mathrm{kg}(1 \mathrm{~h}$ after administration) and at $10 \mathrm{mg} / \mathrm{kg}(1,2,3$, and $4 \mathrm{~h}$ after administration). In the positive control experiment, diaze- 

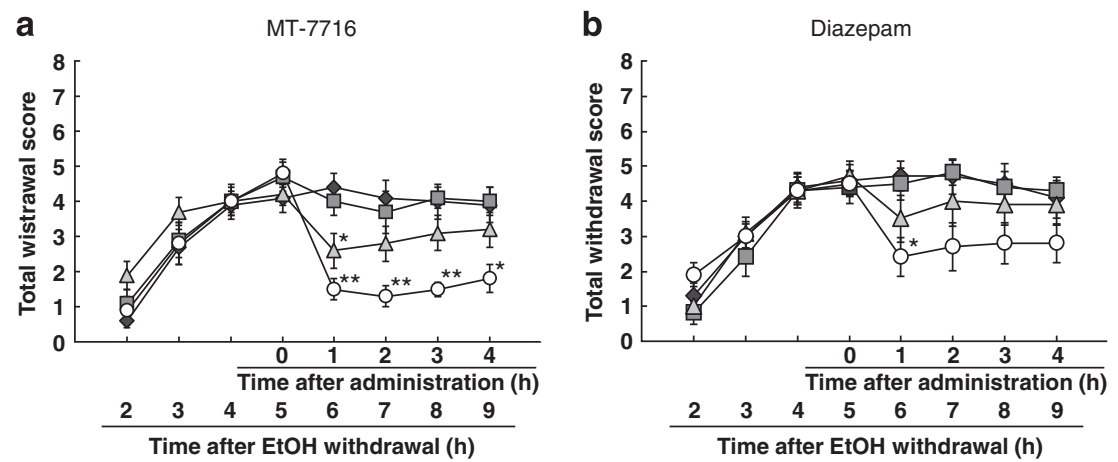

Figure 4 Effects of MT-77I6 (a) and diazepam (b) on ethanol withdrawal symptoms in rats. Animals were orally administered MT-77। 6 at doses of I, 3, and $10 \mathrm{mg} / \mathrm{kg}$ or diazepam at doses of 3,10 , and $30 \mathrm{mg} / \mathrm{kg}$ at $5 \mathrm{~h}$ after ethanol withdrawal. Vehicle ( $), M T-77161 \mathrm{mg} / \mathrm{kg}(\square), 3 \mathrm{mg} / \mathrm{kg}(\triangle), 10 \mathrm{mg} / \mathrm{kg}(\bigcirc)$, diazepam $3 \mathrm{mg} / \mathrm{kg}(\square), 10 \mathrm{mg} / \mathrm{kg}(\triangle)$, and $30 \mathrm{mg} / \mathrm{kg}(\mathrm{O})$. Each point indicates the mean \pm SEM of $9-10$ rats. No statistical analysis was done at $2-4 \mathrm{~h}$ after ethanol withdrawal. No significant difference was observed at $5 \mathrm{~h}$ (vs vehicle, Steel's test). $* 0<0.05$, ** $p<0.0$ I vs vehicle (Dunnett's multiple comparison test for area under curve (AUC) of 6-9h, followed by Steel's test at each time point).

pam, a drug clinically used to treat alcohol withdrawal, also significantly decreased total scores at a dose of $30 \mathrm{mg} / \mathrm{kg}$. The effect was significant at $1 \mathrm{~h}$ into withdrawal, but not at other time points. The lower dose diazepam did not produce significant effects.

\section{DISCUSSION}

Chronic oral treatment with the novel selective NOP receptor agonist MT-7716 significantly and dose-dependently reduced alcohol drinking in msP rats. Interestingly, this effect took 3-4 days of treatment to appear, increased throughout the remaining treatment period, and persisted for several days during the posttreatment phase. At the highest MT-7716 dose tested $(3 \mathrm{mg} / \mathrm{kg})$, daily ethanol consumption reached the minimum level during the late treatment period and the early posttreatment phase (average suppression $\sim 53 \%$ ), to gradually recover toward the end of the experiment. Interestingly, over the same time interval a compensatory increase of water intake was observed. Food consumption was reduced by MT-7716 treatment but only during early treatment phase, indicating that this effect is independent from the effect of the NOP agonist on alcohol consumption. Naltrexone $(30 \mathrm{mg} / \mathrm{kg})$, used here as a positive control, also reduced alcohol intake at the beginning of the treatment but tolerance developed rapidly and the effect disappeared during the posttreatment period.

Ro 64-6198 was the first nonpeptidic and brainpenetrating full agonist at NOP receptor (Jenck et al, 2000), which was tested on alcohol drinking (Kuzmin et al, 2007). In this first study where heterogeneous Wistar rats were used, reduction of alcohol self-administration following compound administration was found. However, in a later study the opposite effect was found in msP rats (Economidou et al, 2006). The increased consumption in msP rats following Ro 64-6198 was blocked by naloxone, suggesting that residual $\mu$-opioid receptor agonistic activity of Ro 64-6198 may have been responsible for this effect (Economidou et al, 2006). This hypothesis was further supported by data obtained with buprenorphine, which acts as a partial agonist at $\mu$-opioid and NOP receptors (Cowan et al, 1977; Lutfy et al, 2003; Rosenbaum et al, 1985; Rovati et al, 1987; Sadee et al, 1982). In fact, low doses of buprenorphine facilitated alcohol drinking by stimu- lation of $\mu$-opioid receptors, while at higher doses the drug reduced drinking by activation of NOP receptors (Ciccocioppo et al, 2007). In receptor binding experiments, we demonstrated that MT-7716 has $\sim 170$-fold higher affinity for the NOP receptor over the $\mu$-opioid receptor compared with the only 30-fold difference of Ro 64-6198. Hence, MT-7716 is superior to Ro 64-6198 in terms of both NOP affinity and selectivity, which may explain its pronounced inhibitory effects on alcohol drinking.

Furthermore, in a recent set of experiment we found that MT-7716 reduced alcohol drinking in post-dependent Wistars but not in nondependent rats. This further support the potential of this compound in alcohol addiction treatment.

Subsequently, to evaluate the effect of MT-7716 on cueinduced reinstatement, we trained rats in an extinction reinstatement procedure where re-exposure to environmental stimuli predictive of alcohol availability elicited a robust resumption of lever responding (Ciccocioppo et al, 2001, 2002b). Chronic MT-7716 elicited a marked inhibition of cue$(\mathrm{S}+)$ induced reinstatement of alcohol seeking, whereas lever pressing associated with water paired cues $(\mathrm{S}-$ ) remained very low in the reinstatement test and was not affected by MT7716. These data confirm previous finding showing that acute intracranial injection of $\mathrm{N} / \mathrm{OFQ}$ significantly reduced cueinduced alcohol reinstatement in msP rats (Ciccocioppo et al, 2004b). The present study demonstrated that this effect persists over chronic activation of NOP receptors following repeated MT-7716 administrations.

Another major determinant of reinstatement to alcohol seeking is stress. Yohimbine, an $\alpha 2$ - adrenoreceptor antagonist, increases cell firing and release of brain noradrenaline, acting as a pharmacological stressor (Abercrombie et al, 1988; Aghajanian and VanderMaelen, 1982; Holmberg et al, 1962; Le et al, 2005; Lee et al, 2004). Yohimbine is known to increase alcohol craving in humans (Charney et al, 1983; Umhau et al, 2011) and to reinstate alcohol seeking following extinction in rats trained to self-administer alcohol (Le et al, 2005; Marinelli et al, 2007).

A very recent meta-analysis study revealed that in the rats the stress-induced reinstatement of alcohol drinking obtained with yohimbine is comparable in size to that produced by exposure to electric footshock (Noori et al, 2014). This stressor was therefore used to further investigate the ability of MT-7716 to prevent reinstatement. The 
findings confirmed that chronic treatment with this NOP agonist significantly reduced reinstatement of alcohol seeking induced by yohimbine. Moreover, in this case, results confirm previous findings with N/OFQ showing that direct infusion of the peptide into the lateral cerebral ventricle blocks footshock stress-induced reinstatement of alcohol seeking in rats (Martin-Fardon et al, 2000). Of note, chronic MT-7716 was effective in preventing cue- and stress-induced reinstatement at comparable or to even lower doses than those needed to attenuate alcohol drinking. Conversely, in previous work following acute ICV N/OFQ injection reinstatement behavior was attenuated at doses higher to those required to reduce drinking (Ciccocioppo et al, 2004b; Martin-Fardon et al, 2000). This observation supports the high potential of systemic NOP agonism in alcoholism and indicates that chronic administration of agents acting through this mechanism may lead to even more pronounced efficacy compared with what has been observed in earlier studies following acute administration of the endogenous ligand.

Over the recent years the mechanisms through which activation of NOP receptors leads to these multiple actions on alcohol's neurobehavioral effects has been subject to extensive investigation. It has been demonstrated that NOP receptors are located in brain areas associated with motivation and addiction (eg, amygdala, mPFC, ventral tegmental area (VTA), lateral hypothalamus, BNST, and nucleus accumbens) (Darland et al, 1998; Neal et al, 1999) and it has been hypothesized that the inhibition of the reinforcing properties of drugs of abuse by activation of NOP receptors may be mediated by the ability of NOP agonists to attenuate drug-induced stimulation of VTA dopaminergic neurons (Ciccocioppo et al, 2000a; Schank et al, 2012; Zaveri, 2011). The modulatory role of N/OFQ on mesocorticolimbic DA activity may also contribute to NOP agonist-induced reinstatement prevention, as activation of this catecholaminergic neurocircuitry appears to mediate several aspects of both cue and stress-induced reinstatement to drug seeking (McFarland et al, 2004; Sun, 2011; Weiss et al, 2000). In addition to this dopamine (DA) modulation hypothesis it has been suggested that activation of NOP receptors produces marked functional anti-opioid effects. For instance, intracranial injection of N/OFQ blocked opioid-induced supraspinal analgesia (Mogil et al, 1996a) and, more importantly, attenuated morphine reward measured by conditioned place preference (Ciccocioppo et al, 2000b; Murphy et al, 1999). A neurochemical correlate of N/OFQ ability to attenuate opioid reward was revealed by microdialysis data showing that central injection of the peptide reduced morphine-induced DA release in the NAcc (Di Giannuario et al, 2000). In this respect, the pharmacology of NOP agonists overlaps with that of classical opioid antagonists. Hence, it is not surprising that similar to naltrexone NOP agonists can reduce alcohol drinking and alcohol cue reactivity (Ciccocioppo et al, 2002c; Monti et al, 1999; Rohsenow et al, 2000). Finally, based on the discovery that N/OFQ acts as a functional antagonist of the extrahypothalamic $\mathrm{CRF}_{1}$ receptor system, we have postulated that NOP receptor agonists may attenuate drugseeking and self-administration through their anxiolytic and anti-stress actions (Schank et al, 2012). For example, N/ OFQ blocked the anxiogenic-like effect of CRF and abolished the anorectic effect of restraint stress and CRF, with the BNST being the critical site of interaction between the two systems (Ciccocioppo et al, 2003; Rodi et al, 2008). In addition, in a recent electrophysiological study, it was shown that N/OFQ opposes the ability of CRF to facilitate GABAergic transmission in the CeA (Cruz et al, 2012). Interestingly, this inhibitory effect was more pronounced in animals withdrawn from intoxicating doses of alcohol, which are known to show overactive CRF neurotransmission (Cruz et al, 2012).

Similar to N/OFQ, MT-7716 significantly reduced the increase of GABA release evoked by ethanol in CeA slices of naive rats, through a supposed presynaptic activity (Kallupi et al, 2014).

Noteworthy, the CeA appears to be the brain site of action of N/OFQ on alcohol drinking (Economidou et al, 2008). Hence, the anti-CRF actions mediated by NOP agonism may contribute to the attenuation of both alcohol drinking and stress-induced reinstatement. Taken as a whole, the antiopioid and anti-CRF nature of N/OFQ together with its ability to modulate mesolimbic DA transmission may offer the rationale to explain the effect of NOP agonists on both drinking and reinstatement behavior. In fact, opioid antagonism and attenuation of DA transmission could have a dominant role in the attenuation of alcohol-associated positive reinforcement and cue-induced reinstatement, whereas CRF antagonism could help to counteract negative affect resulting from adaptive changes associated with protracted drug use and stress-induced reinstatement. Another attractive feature of MT-7716 is that it also helps to attenuate the expression of somatic withdrawal in alcohol intoxicated rats. This effect confirms previous findings with N/OFQ (Aujla et al, 2012; Economidou et al, 2011).

Considering the crucial role had by anti-relapse drugs in the pharmacotherapy of alcoholism, MT-7716 could be useful in the symptoms management and in the rehabilitation during protracted alcohol abstinence.

In this respect, the capacity of MT-7716 to attenuate alcohol withdrawal symptom may contribute to increase compliance and higher adherence to the treatment, compared with other medications currently available.

In summary, our results suggest that chronic exposure to MT-7716, a potent brain-penetrating and highly selective NOP receptor agonist (Teshima et al, 2005), attenuates alcohol drinking and cue- as well as stress-induced reinstatement. This finding suggests that activation of NOP receptors may represent an efficacious alternative to classical $\mu$-opioid receptor antagonists (ie, naltrexone) in alcohol addiction. Moreover, an unexpected and potentially promising finding was that chronic activation of NOP receptors by MT-7716 led to a pronounced inhibition of alcohol drinking lasting for several days after treatment discontinuation. Based on the pharmacokinetic profile of MT-7716, it is difficult to explain this lasting effect, because the drug is completely eliminated in few hours $\left(T_{1 / 2}\right.$ in rats is about $\left.1 \mathrm{~h}\right)$ and does not accumulate. One possibility is that following protracted treatment adaptive changes may occur in the N/OFQ system, which may contribute to the effects of NOP agonists on alcohol drinking. Clearly, this phenomenon requires further investigation; however, the efficacy of MT-7716 following chronic administration and its lasting effect represent relevant pharmacological properties in the path toward the 
clinical development of this class of compounds for the treatment of alcoholism. Very recently, small molecules $\left[{ }^{11} \mathrm{C}\right]$-labeled PET ligands for NOP receptors have been developed (Kimura et al, 2011; Lohith et al, 2012; Pike et al, 2011). Studies with these ligand revealed high density binding sites throughout the CNS of healthy human volunteers. Availability of these PET tracers will facilitate the clinical investigation of compounds acting on NOP receptors and likely will expedite the clinical development of MT-7716 or other NOP agents (Ubaldi et al, 2013).

\section{FUNDING AND DISCLOSURE}

The authors declare no conflict of interest.

\section{ACKNOWLEDGEMENTS}

This study was supported by NIH AA014351 (FW) and AA017447 (MR). Support was also provided by the Mitsubishi Tanabe Pharma Corporation (grant to RC).

\section{REFERENCES}

Abercrombie ED, Keller RW Jr, Zigmond MJ (1988). Characterization of hippocampal norepinephrine release as measured by microdialysis perfusion: pharmacological and behavioral studies. Neuroscience 27: 897-904.

Aghajanian GK, VanderMaelen CP (1982). alpha 2-adrenoceptormediated hyperpolarization of locus coeruleus neurons: intracellular studies in vivo. Science 215: 1394-1396.

Aujla H, Cannarsa R, Romualdi P, Ciccocioppo R, Martin-Fardon R, Weiss F (2012). Modification of anxiety-like behaviors by nociceptin/orphanin FQ (N/OFQ) and time-dependent changes in N/OFQ-NOP gene expression following ethanol withdrawal. Addict Biol 18: 467-479.

Cannella N, Economidou D, Kallupi M, Stopponi S, Heilig M, Massi $M$ et al (2009). Persistent increase of alcohol-seeking evoked by neuropeptide S: an effect mediated by the hypothalamic hypocretin system. Neuropsychopharmacology 34: 2125-2134.

Charney DS, Heninger GR, Redmond DE Jr (1983). Yohimbine induced anxiety and increased noradrenergic function in humans: effects of diazepam and clonidine. Life Sci 33: 19-29.

Ciccocioppo R, Angeletti S, Panocka I, Massi M (2000a). Nociceptin/ orphanin FQ and drugs of abuse. Peptides 21: 1071-1080.

Ciccocioppo R, Angeletti S, Sanna PP, Weiss F, Massi M (2000b). Effect of nociceptin/orphanin FQ on the rewarding properties of morphine. Eur J Pharmacol 404: 153-159.

Ciccocioppo R, Angeletti S, Weiss F (2001). Long-lasting resistance to extinction of response reinstatement induced by ethanolrelated stimuli: role of genetic ethanol preference. Alcohol Clin Exp Res 25: 1414-1419.

Ciccocioppo R, Biondini M, Antonelli L, Wichmann J, Jenck F, Massi M (2002a). Reversal of stress- and CRF-induced anorexia in rats by the synthetic nociceptin/orphanin FQ receptor agonist, Ro 64-6198. Psychopharmacology (Berl) 161: 113-119.

Ciccocioppo R, Cippitelli A, Economidou D, Fedeli A, Massi M (2004a). Nociceptin/orphanin FQ acts as a functional antagonist of corticotropin-releasing factor to inhibit its anorectic effect. Physiol Behav 82: 63-68.

Ciccocioppo R, Economidou D, Fedeli A, Angeletti S, Weiss F, Heilig $M$ et al (2004b). Attenuation of ethanol self-administration and of conditioned reinstatement of alcohol-seeking behaviour by the antiopioid peptide nociceptin/orphanin FQ in alcohol-preferring rats. Psychopharmacology 172: 170-178.

Ciccocioppo R, Economidou D, Rimondini R, Sommer W, Massi M, Heilig M (2007). Buprenorphine reduces alcohol drinking through activation of the nociceptin/orphanin FQ-NOP receptor system. Biol Psychiatry 61: 4-12.

Ciccocioppo R, Fedeli A, Economidou D, Policani F, Weiss F, Massi M (2003). The bed nucleus is a neuroanatomical substrate for the anorectic effect of corticotropin-releasing factor and for its reversal by nociceptin/orphanin FQ. J Neurosci 23: 9445-9451.

Ciccocioppo R, Martin-Fardon R, Weiss F (2002b). Effect of selective blockade of $\mathrm{mu}(1)$ or delta opioid receptors on reinstatement of alcohol-seeking behavior by drug-associated stimuli in rats. Neuropsychopharmacology 27: 391-399.

Ciccocioppo R, Polidori C, Antonelli L, Salvadori S, Guerrini R, Massi M (2002c). Pharmacological characterization of the nociceptin receptor which mediates reduction of alcohol drinking in rats. Peptides 23: 117-125.

Cowan A, Lewis JW, Macfarlane IR (1977). Agonist and antagonist properties of buprenorphine, a new antinociceptive agent. $\mathrm{Br} J$ Pharmacol 60: 537-545.

Cruz MT, Herman MA, Kallupi M, Roberto M (2012). Nociceptin/ orphanin FQ blockade of corticotropin-releasing factor-induced gamma-aminobutyric acid release in central amygdala is enhanced after chronic ethanol exposure. Biol Psychiatry 71: 666-676.

Darland T, Heinricher MM, Grandy DK (1998). Orphanin FQ/ nociceptin: a role in pain and analgesia, but so much more. Trends Neurosci 21: 215-221.

Di Giannuario A, Pieretti S (2000). Nociceptin differentially affects morphine-induced dopamine release from the nucleus accumbens and nucleus caudate in rats. Peptides 21: 1125-1130.

Economidou D, Cippitelli A, Stopponi S, Braconi S, Clementi S, Ubaldi $M$ et al (2011). Activation of brain NOP receptors attenuates acute and protracted alcohol withdrawal symptoms in the rat. Alcohol Clin Exp Res 35: 747-755.

Economidou D, Fedeli A, Fardon RM, Weiss F, Massi M, Ciccocioppo R (2006). Effect of novel nociceptin/orphanin FQNOP receptor ligands on ethanol drinking in alcohol-preferring msP rats. Peptides 27: 3299-3306.

Economidou D, Hansson AC, Weiss F, Terasmaa A, Sommer WH, Cippitelli A et al (2008). Dysregulation of nociceptin/orphanin FQ activity in the amygdala is linked to excessive alcohol drinking in the rat. Biol Psychiatry 64: 211-218.

Hansson AC, Cippitelli A, Sommer WH, Fedeli A, Björk K, Soverchia L et al (2006). Variation at the rat Crhr1 locus and sensitivity to relapse into alcohol seeking induced by environmental stress. Proc Natl Acad Sci USA 103: 15236-15241.

Holmberg G, Gershon S, Beck LH (1962). Yohimbine as an autonomic test drug. Nature 193: 1313-1314.

Huang J, Young B, Pletcher MT, Heilig M, Wahlestedt C (2008). Association between the nociceptin receptor gene (OPRL1) single nucleotide polymorphisms and alcohol dependence. Addict Biol 13: 88-94.

Jenck F, Wichmann J, Dautzenberg FM, Moreau JL, Ouagazzal AM, Martin JR et al (2000). A synthetic agonist at the orphanin FQ/ nociceptin receptor ORL1: anxiolytic profile in the rat. Proc Natl Acad Sci USA 97: 4938-4943.

Kallupi M, Oleata CS, Luu G, Teshima K, Ciccocioppo R, Roberto M (2014). MT-7716, a novel selective nonpeptidergic NOP receptor agonist, effectively blocks ethanol-induced increase in GABAergic transmission in the rat central amygdala. Front Integr Neurosci 8: 18.

Kimura Y, Fujita M, Hong J, Lohith TG, Gladding RL, Zoghbi SS et al (2011). Brain and whole-body imaging in rhesus monkeys of $11 \mathrm{C}-\mathrm{NOP}-1 \mathrm{~A}$, a promising PET radioligand for nociceptin/ orphanin FQ peptide receptors. J Nucl Med 52: 1638-1645.

Koster A, Montkowski A, Schulz S, Stube EM, Knaudt K, Jenck F et al (1999). Targeted disruption of the orphanin FQ/nociceptin gene increases stress susceptibility and impairs stress adaptation in mice. Proc Natl Acad Sci USA 96: 10444-10449.

Kotlinska J, Wichmann J, Legowska A, Rolka K, Silberring J (2002). Orphanin FQ/nociceptin but not Ro 65-6570 inhibits the 
expression of cocaine-induced conditioned place preference. Behav Pharmacol 13: 229-235.

Kuzmin A, Kreek MJ, Bakalkin G, Liljequist S (2007). The nociceptin/orphanin FQ receptor agonist Ro 64-6198 reduces alcohol self-administration and prevents relapse-like alcohol drinking. Neuropsychopharmacology 32: 902-910.

Le AD, Harding S, Juzytsch W, Funk D, Shaham Y (2005). Role of alpha-2 adrenoceptors in stress-induced reinstatement of alcohol seeking and alcohol self-administration in rats. Psychopharmacology (Berl) 179: 366-373.

Lee B, Tiefenbacher S, Platt DM, Spealman RD (2004). Pharmacological blockade of alpha2-adrenoceptors induces reinstatement of cocaine-seeking behavior in squirrel monkeys. Neuropsychopharmacology 29: 686-693.

Lohith TG, Zoghbi SS, Morse CL, Araneta MF, Barth VN, Goebl NA et al (2012). Brain and whole-body imaging of nociceptin/ orphanin FQ peptide receptor in humans using the PET ligand 11C-NOP-1A. J Nucl Med 53: 385-392.

Lutfy K, Eitan S, Bryant CD, Yang YC, Saliminejad N, Walwyn W et al (2003). Buprenorphine-induced antinociception is mediated by mu-opioid receptors and compromised by concomitant activation of opioid receptor-like receptors. J Neurosci 23: 10331-10337.

Macey DJ, Schulteis G, Heinrichs SC, Koob GF (1996). Timedependent quantifiable withdrawal from ethanol in the rat: effect of method of dependence induction. Alcohol 13: 163-170.

Marinelli PW, Funk D, Juzytsch W, Harding S, Rice KC, Shaham Y et al (2007). The CRF1 receptor antagonist antalarmin attenuates yohimbine-induced increases in operant alcohol self-administration and reinstatement of alcohol seeking in rats. Psychopharmacology 195: 345-355.

Marquez P, Hamid A, Lutfy K (2013). The role of NOP receptors in psychomotor stimulation and locomotor sensitization induced by cocaine and amphetamine in mice. Eur J Pharmacol 707: 41-45.

Martin-Fardon R, Ciccocioppo R, Massi M, Weiss F (2000). Nociceptin prevents stress-induced ethanol- but not cocaineseeking behavior in rats. Neuroreport 11: 1939-1943.

McFarland K, Davidge SB, Lapish CC, Kalivas PW (2004). Limbic and motor circuitry underlying footshock-induced reinstatement of cocaine-seeking behavior. J Neurosci 24: 1551-1560.

Meunier JC, Mollereau C, Toll L, Suaudeau C, Moisand C, Alvinerie P et al (1995). Isolation and structure of the endogenous agonist of opioid receptor-like ORL1 receptor. Nature 377: 532-535.

Mogil JS, Grisel JE, Reinscheid RK, Civelli O, Belknap JK, Grandy DK (1996a). Orphanin FQ is a functional anti-opioid peptide. Neuroscience 75: 333-337.

Mogil JS, Kest B, Sadowski B, Belknap JK (1996b). Differential genetic mediation of sensitivity to morphine in genetic models of opiate antinociception: influence of nociceptive assay. J Pharmacol Exp Ther 276: 532-544.

Monti PM, Rohsenow DJ, Hutchison KE, Swift RM, Mueller TI, Colby SM et al (1999). Naltrexone's effect on cue-elicited craving among alcoholics in treatment. Alcohol Clin Exp Res 23: 1386-1394.

Murphy NP, Lee Y, Maidment NT (1999). Orphanin FQ/nociceptin blocks acquisition of morphine place preference. Brain Res $\mathbf{8 3 2}$ : $168-170$.

Neal CR, Mansour A, Reinscheid R, Nothacker HP, Civelli O, Akil H et al (1999). Opioid receptor-like (ORL1) receptor distribution in the rat central nervous system: Comparison of ORL1 receptor mRNA expression with I-125-[(14)Tyr]-orphanin FQ binding. J Compar Neurol 412: 563-605.

Noori HR, Helinski S, Spanagel R (2014). Cluster and metaanalyses on factors influencing stress-induced alcohol drinking and relapse in rodents. Addict Biol 19: 225-232.

Pike VW, Rash KS, Chen Z, Pedregal C, Statnick MA, Kimura Y et al (2011). Synthesis and evaluation of radioligands for imaging brain nociceptin/orphanin FQ peptide (NOP) receptors with positron emission tomography. J Med Chem 54: 2687-2700.

Reinscheid RK, Nothacker HP, Bourson A, Ardati A, Henningsen RA, Bunzow JR et al (1995). Orphanin FQ: a neuropeptide that activates an opioidlike G protein-coupled receptor. Science 270: 792-794.

Rodi D, Zucchini S, Simonato M, Cifani C, Massi M, Polidori C (2008). Functional antagonism between nociceptin/orphanin FQ (N/OFQ) and corticotropin-releasing factor (CRF) in the rat brain: evidence for involvement of the bed nucleus of the stria terminalis. Psychopharmacology (Berl) 196: 523-531.

Rohsenow DJ, Monti PM, Hutchison KE, Swift RM, Colby SM, Kaplan GB (2000). Naltrexone's effects on reactivity to alcohol cues among alcoholic men. J Abnorm Psychol 109: 738-742.

Rosenbaum JS, Holford NH, Sadee W (1985). In vivo receptor binding of opioid drugs at the mu site. J Pharmacol Exp Ther 233: 735-740.

Rovati LC, Pazzucconi F, Panerai AE (1987). Involvement of mu-receptor and kappa-receptor in the analgesic effect of buprenorphine. Med Sci Res Biochem 15: 659-660.

Sadee W, Rosenbaum JS, Herz A (1982). Buprenorphine: differential interaction with opiate receptor subtypes in vivo. J Pharmacol Exp Ther 223: 157-162.

Sakoori K, Murphy NP (2009). Enhanced nicotine sensitivity in nociceptin/orphanin FQ receptor knockout mice. Neuropharmacology 56: 896-904.

Schank JR, Ryabinin AE, Giardino WJ, Ciccocioppo R, Heilig M (2012). Stress-related neuropeptides and addictive behaviors: beyond the usual suspects. Neuron 76: 192-208.

Sun W (2011). Dopamine neurons in the ventral tegmental area: drug-induced synaptic plasticity and its role in relapse to drug-seeking behavior. Curr Drug Abuse Rev 4: 270-285.

Teshima K, Minoguchi M, Tounai S, Ashimori A, Eguchi J, Allen $\mathrm{CN}$ et al (2005). Nonphotic entrainment of the circadian body temperature rhythm by the selective ORL1 receptor agonist W-212393 in rats. Br J Pharmacol 146: 33-40.

Ubaldi M, Bifone A, Ciccocioppo R (2013). Translational approach to develop novel medications on alcohol addiction: focus on neuropeptides. Curr Opin Neurobiol 23: 684-691.

Umhau JC, Schwandt ML, Usala J, Geyer C, Singley E, George DT et al (2011). Pharmacologically induced alcohol craving in treatment seeking alcoholics correlates with alcoholism severity, but is insensitive to acamprosate. Neuropsychopharmacology 36: $1178-1186$.

Weiss F, Maldonado-Vlaar CS, Parsons LH, Kerr TM, Smith DL, Ben-Shahar O (2000). Control of cocaine-seeking behavior by drug-associated stimuli in rats: effects on recovery of extinguished operant-responding and extracellular dopamine levels in amygdala and nucleus accumbens. Proc Natl Acad Sci USA 97: 4321-4326.

Xuei X, Flury-Wetherill L, Almasy L, Bierut L, Tischfield J, Schuckit $\mathrm{M}$ et al (2008). Association analysis of genes encoding the nociceptin receptor (OPRL1) and its endogenous ligand (PNOC) with alcohol or illicit drug dependence. Addict Biol 13: 80-87.

Zaveri NT (2011). The nociceptin/orphanin FQ receptor (NOP) as a target for drug abuse medications. Curr Top Med Chem 11: 1151-1156.

Zhang H, Wang F, Kranzler HR, Gelernter J (2013). Profiling of childhood adversity-associated DNA methylation changes in alcoholic patients and healthy controls. PLoS One 8: e65648.

Zhao RJ, Woo RS, Jeong MS, Shin BS, Kim DG, Kim KW (2003). Orphanin FQ/nociceptin blocks methamphetamine place preference in rats. Neuroreport 14: 2383-2385.

Supplementary Information accompanies the paper on the Neuropsychopharmacology website (http://www.nature.com/npp) 